\title{
WHOSE DEMOCRACY? The Greek Crisis, Public Money and the EUROZONE
}

\author{
Daniel Haitas
}

\begin{abstract}
In recent times much of the news and political discussion in Europe and beyond has been dominated by the issue of the present situation in Greece, in particular its debt problem, relationship to other EU Member States and place within the Eurozone. The major source of contention has been the differing opinions about the measures that Greece should implement in order to receive bailout money so as to avoid defaulting on its debts and remain a member of the Eurozone. The Syriza government employed rhetoric emphasising the democratic will of the Greek people in order to renegotiate the country's relationship to its creditors on more favourable terms. However, it often seems to be forgotten by those who promote and support this narrative that in the other 18 Eurozone countries there is also a democratic will and voting public which is concerned in particular with the way in which tax-payer money and public funds are to be spent.
\end{abstract}

Keywords: Greece, Eurozone, financial crisis, democracy, bailout, Germany

\section{Introduction}

In recent times much of the news and political discussion in Europe and beyond has been dominated by the issue of the present situation in Greece, in particular its debt problem, relationship to other EU Member States and place within the Eurozone. The major source of contention has been the differing opinions about the measures that Greece should implement in order to receive bailout money so as to avoid defaulting on its debts and remain a member of the Eurozone.

\section{The Greek Crisis}

In 2009 it came to light that after decades of economic mismanagement and irresponsible fiscal practices Greece was entering into a crisis stage, with a debt spiralling out of control and facing the very real prospect of default. In order to avoid this Greece received bailout packages from the EC, IMF, and ECB (the so-called troika) in exchange for which there was an 
implementation of various austerity measures and structural reforms, which took a heavy toll on Greek society.

As a response to this situation, the radical leftist Syriza party led by Alexis Tsipras won the elections in January of this year on a wave of anti-austerity feeling and protest. The new government promised to roll back austerity measures and renegotiate Greece's place within the Eurozone and to challenge the policies of its European partners and creditors. The Syriza government laid a particular emphasis on the democratic will of the Greek people and at times used the rhetoric of oppression and liberation in relation to Greece's creditors (in particular, Germany) (Stevis \& Thomas, 2015). This culminated in the referendum held on July 5 which asked the Greek people whether they accepted a bailout proposal put forward by the troika (a proposal which at the time of the referendum had actually expired) which led to an overwhelming "No" vote in support of the government's position (Kambas, 2015). This result was described by Tsipras as a ,victory of democracy" (CBS News, 2015).

However, it often seems to be forgotten by those who promote and support the above narrative that in the other 18 Eurozone countries there is also a democratic will and voting public which is concerned in particular with the way in which tax-payer money and public funds are to be spent, a concern which relates directly to the Greek situation, as the citizens of these countries have contributed to past bailouts for Greece, and will fund any future financial assistance and possible debt forgiveness (the so-called „,debt haircut") for the country. This factor, which is strongly tied to a scepticism about the ability of the Greek state and economy to reform and restructure, coupled with what was seen by many as the erratic, provocative and obstructionist attitudes and negotiating tactics employed by the Syriza government, led to a subsequent loss of trust and the hardening of attitudes among substantial segments of the citizenry of certain Eurozone states. Among these is Germany, which represents the economic powerhouse of Europe, and Slovakia and the Baltic states, which are smaller postcommunist countries that have also gone through their own experiences of austerity and economic hardship. Here we shall briefly survey the attitudes of certain elements of the governments and general publics of these countries in relation to the issue of funding for a new bailout agreement for Greece in order to obtain a more complete and balanced picture of the present crisis in the Eurozone.

\section{The German Response}

Germany is without doubt the most important economy in the Eurozone and Greece's largest creditor (Taylor, 2015), and it can be said that often in reality the negotiations between Greece and her Eurozone partners were in essence actually between Greece and Germany. The official German attitude since the beginning of the Greek debt crisis in 2009 has been that it supports Greece's continued membership in the Eurozone, however, it expects deep and comprehensive reforms from the Greek side in return for financial assistance. However, what many saw as the anti-German rhetoric and actions of the Greek government, as well as its behaviour during the 
protracted negotiations over the first half of this year, led to a subsequent loss of trust and a hardening of attitudes both on the part of the German government and the wider German public (Stevis \& Thomas, 2015), which in many ways was exemplified by the strained relationship between the then Greek Finance Minister Yanis Varoufakis and German Foreign Minister Wolfgang Schäuble. The acrimony between the two sides perhaps reached its zenith when Schäuble suggested that Greece should temporarily leave the Eurozone for a period of 5 years in order to be able to receive debt relief and get its financial affairs in order (Martin, 2015). In the end, a new bailout agreement was reached which has been universally acknowledged as being very stringent and which represents a caving in and defeat for the Greek government in the face of the firm line taken by Germany and her supporters within the Eurozone, a firmness which it is believed was reinforced by the political events and trends in Greece since the election of the Syriza government (Kambas \& Williams, 2015). As Slovak Finance Minister Peter Kazimir tweeted, „\#Greece compromise we reached this morning is tough for Athens because it's the result of their "Greek Spring” \#eurozone" (Slovak Finance Minister, 2015).

The German public on the whole responded very favourably to the tough stance taken by their government in the negotiations with Greece. According to one poll, 55\% of Germans support the line adopted by Chancellor Angela Merkel, and in fact a third of those polled wished that she had taken an even tougher position (Bolton, 2015). It is also is very telling that after an agreement was reached with Greece, Chancellor Merkel and Finance Minister Schäuble soared in their approval ratings, with the latter reaching 70\% according to one poll (Cullen, 2015). Furthermore, according to another poll, if elections were to be held in Germany now, Merkel's Christian Democratic Union would come close to winning an outright majority in the Bundestag, something which has not occurred since the days of Konrad Adenauer (Regina, 2015). Despite this, Merkel has faced strong internal opposition from certain quarters to any new bailout for Greece, with 60 lawmakers from her own government rejecting the deal in the Bundestag (Carrel \& Rinke, 2015).

Another poll conducted in June which questioned Germans on Greece's continued Eurozone membership recorded that 53\% wished to see Greece leave the currency union and only $29 \%$ actively supported Greece remaining, though a latter poll recorded in July saw this attitude soften somewhat, with $47 \%$ opposed to Greece remaining in the Eurozone, and 37\% being in favour (McHugh, 2015). And very interestingly, while the general feeling and rhetoric in Greece in the aftermath of the new bailout agreement is that the country was defeated and humiliated by Germany and it sallies (Kambas \& Williams, 2015), certain segments of the German media and public opinion believe that in fact the Greeks actually managed to fool the Germans and thus resent that fact that they will receive their money again in spite of what many of them view as months of provocation and hostility. For example, in the aftermath of the agreement the front page of Germany's most popular newspaper, Bild, proclaimed „Merkel Saves Greece With Our Money!" (Davidson, 2015) and another such headline from the same source also read „Tsipras laughs and we pay, pay, pay” (Scally, 2015). 


\section{The Baltic states' advice}

Slovakia and the Baltic states represent very different sorts of countries to Germany, being considered as the „poorer” states of the Eurozone. When dealing with the attitude of their citizenry to the Greek situation, one frequently encounters two specific complaints. One is that they themselves have undergone harsh austerity measures in the post-communist period, having had no choice but to endure and accept them, and thus they lack sympathy for Greeks who protest such measures. The other is that they believe that Greeks, despite the crisis, enjoy a higher standard of living and receive higher wages than they do. Thus, many of them cannot understand why they must contribute their money towards any further financial assistance for Greece. For example, in one report from Latvia, a local woman said, „I think that the Greeks have to face up to the challenges that we experienced. They have to tighten their belts...I suffered during the crisis, too, and they have to accept the situation. I did, life goes on" (Deutsche Welle, 2015). In the same article, a certain Riga resident stated, „I think they're used to the good life and generous benefits ... I heard Greek pensioners complaining on the news that their pension was 2,600 euros...but now its 1,300. Well, 1,300 euros! If you compare that to our pensions of 300 and 400 euros - well, judge for yourselves!” (Deutsche Welle, 2015). In a report from Slovakia, a Bratislava resident said „I heard some Greeks have pensions over 1,000 euros ... a month. That's outrageous. I refuse to pay for their debt while they are making fortunes compared to my salary" (Ekathimerini, 2015). From Estonia, the editor of one of the country's leading newspapers stated that, „Estonians don't really understand the Greek attitude. We are used to saving and living frugally" (Ekathimerini, 2015). Regardless of the accuracy of such statements with regards to the Greek economic reality, they reflect a very widely held belief among many of the citizens of these countries that Greeks have a higher standard of living and more generous welfare system then their own, and thus they greatly resent the idea of having to help finance such as system.

The political leaders of these countries have also expressed frustration and a tough line towards Greece. During the course of negotiations Lithuanian President Dalia Grybauskaite said „If someone changes their options every week, to gain trust is not easy...Everyday costs a lot for Greece, especially for the Greek people" and that ,for the Greek government everyday is mañana" (Szu Ping Chang, 2015). Estonian Prime Minister Taavi Rõivas also stated that „Trust is renewable but it doesn't happen very easily. Optimism is our moral duty but it's clear there it isn't much reason for optimism" (Szu Ping Chang, 2015). In relation to the issue of resistance to Greece having to adopt certain austerity measures Slovak Prime Minister Robert Fico made the statement that, If Slovakia managed to carry out reforms then Greece has to be able to do it, too, there is no room for mercy on our side" (Szu Ping Chang, 2015). Slovak Finance Minister Peter Kazimir, in the wake of Greece's July referendum, said that „With the result of the referendum, possible crisis scenario, the gradual withdrawal of Greece from the Eurozone, is unfolding", this being the first statement by a Eurogroup finance minister signifying that the „No" vote in the referendum 
could lead to a so-called "Grexit” (Ekathimerini, 2015). And on the matter of the possibility of debt forgiveness, Prime Minister Fico even went as far as to say that it would be ,immoral” to do such a thing and that „Greeks must pay a tax for how they behaved in the past" (Jancarikova, 2015).

\section{Closing Remarks}

Though it appears that Greece shall receive a new bailout and will continue to remain a member of the Eurozone for the time being, this will very much be on the terms of its creditors, terms which are based to a large extent on the concerns, interests, scepticism and exasperation of the citizenry and political class of the various Eurozone states. Based on the above analysis it can be concluded that one of the most important lessons to be learnt from the Greek crisis is that in such a structure as the Eurozone, with the interdependence that it causes for both powerful and weaker states alike, the democratic will of one particular nation cannot be discussed in isolation, as the democracy and will of all Member States and the way in which they wish to see their public funds spent must be taken into account and considered, and with decisions made accordingly. On a final note, it is worth remembering that unlike in Greece, there have been no referendums in the other Eurozone states asking citizens their opinion on bailout proposals for Greece or whether the country should remain a member of the Eurozone, and based on the above analysis, if they were to take place, the results would most probably not be positive and would most likely see Greece forced to leave the Eurozone.

\section{List of References:}

Baltic states' advice to Greece: 'Do as we did', Deutsche Welle, 20 July, 2015

Bolton, D. (2015), More than half of German's support Angela Merkel's tough stance on Greece. The Independent, July 15, 2015

Carrel, P. \& Rinke, A. (2015), In Germany, 60 conservative MPs oppose Merkel course on Greece. Reuters. August 18, 2015

Critical scrambling follows Greek bailout deal rejection, CBS News, July 6, 2015

Cullen, A. (2015), Schaeuble Popularity Soars as German's Doubt Greece's Euro Future. Bloomberg. July 3, 2015

Davidson, L. (2015), Merkel saves Greece with our money: What European papers say about Greece. The Telegraph. July 14, 2015

Scally, D. (2015), 'Tsipras laughs and we pay, pay, pay' says German Bild tabloid, The Irish Times, July 11, 2015

Eurozone's poorer nations take hard line on Greece, Ekathimerini, 6 July, 2015 Kambas \& Williams (2015), Angry at demands.

Kambas, M. (2015), Questions, conflicts mark path to Greek bailout referendum. Reuters, June 29, 2015

Martin, M. (2015), German Economy Minister criticizes Schaeuble's proposal for temporary Grexit. Reuters, July 19, 2015

McHugh, J. (2015), Greek Debt Crisis: Poll Shows Finland and Germany Still Tough on Greece, but Support for a Grexit Wanes. International Business Times. July 10, 2015

Regina, A. (2015), The Economist. August 22, 2015

Slovak Finance Minister (2015), slammed Greek ex-counterpart over return to drachma. The Slovak Spectator, July 28, 2015 
Stevis, M. \& Thomas, A. (2015), Greek, German Tensions Turn to Open Resentment as Referendum Looms. The Wall Street Journal, July 4, 2015

Szu Ping Chang, The countries that wanted Greece out of the Eurozone, The Telegraph, July 13, 2015

Jancarikova, T. (2015), "Eurozone's have-nots ask: why should Greece get more than us," Reuters, July 21, 2015

Taylor, P. (2015), How much Greece owes to international creditors. Reuters, June 282015 